Pacific Journal of Mathematics

REMARK ON A PAPER OF TUX CONCERNING
SQUAREFREE NUMBERS IN NON-LINEAR SEQUENCES 


\section{REMARK ON A PAPER OF STUX CONCERNING SQUAREFREE NUMBERS IN NON-LINEAR SEQUENCES}

\section{G. J. RIEGER}

Stux studied squarefree numbers of the form $[f(n)]$; his most interesting application is $f(n)=n^{c}$ for real $c$ with $1<c<$ $4 / 3$. We would like to point out that a stronger result follows immediately from estimates of Deshouillers.

Let $1<c<2, x \geqq 1$; denote by $N_{c}(x ; k, l)$ the number of natural numbers $n \leqq x$ with $\left[n^{c}\right] \equiv 1 \bmod k$. According to [1], we have

$$
\begin{gathered}
N_{c}(x ; k, l)=\frac{x}{k}+O_{c}\left(\left(x^{1+c} k^{-1}\right)^{1 / 3}\right) \quad \text { for } \quad x^{c-5 / 4} \leqq k<x^{c-1 / 2}, \\
N_{c}(x ; k, l)=\frac{x}{k}+O_{c}\left(\left(x^{4+c} k^{-1}\right)^{1 / 7}\right) \text { for } k<x^{c-5 / 4} .
\end{gathered}
$$

Denote by $S_{c}(x)$ the number of squarefree numbers of the form [ $n^{c}$ ] with natural $n \leqq x$; the inclusion-exclusion principle in the form $|\mu(n)|=\sum_{d^{2} \mid n, d>0} \mu(d)$ gives

$$
S_{c}(x)=\sum_{d^{2} \leqq x^{c}} \mu(d) N_{c}\left(x ; d^{2}, 0\right) \quad(x \geqq 1) .
$$

For $d^{2} \geqq x^{c-1 / 2}$ we use the trivial estimate $N_{c}\left(x ; d^{2}, 0\right)=O\left(x^{c} d^{-2}\right)$; using

$$
\sum_{d>t} d^{-2}=O\left(t^{-1}\right) \quad(t \geqq 1)
$$

we obtain

$$
S_{c}(x)=\sum_{d^{2}<x^{c-1 / 2}} \mu(d) N_{c}\left(x ; d^{2}, 0\right)+O\left(x^{(2 c+1) / 4}\right) .
$$

In case $c \leqq 5 / 4$, we use (1) and

$$
\sum_{0<d \leqq t} d^{-2 / 3}=O\left(t^{1 / 3}\right) \quad(t \geqq 1)
$$

in (5); this gives

$$
S_{c}(x)=\sum_{d^{2}<x^{c-1 ! 2}} \mu(d) d^{-2} x+O_{c}\left(x^{(2 x+1) / 4}\right) .
$$

In case $c>5 / 4$, we split the sum in (5) according to $d^{2}<$ or $\geqq x^{c-5 / 4}$ and apply (2) and (1); using $\sum_{0<d \leqq t} d^{-2 / 7}=O\left(t^{5 / 7}\right)(t \geqq 1)$ and (6), we obtain again (7). But (7), $\sum_{d>0} \mu(d) d^{-2}=6 \pi^{-2}$, and (4) give immediately 
THEOREM 1. For real $c$ with $1<c<3 / 2$, we have

$$
S_{c}(x)=6 \pi^{-2} x+O_{c}\left(x^{(2 c+1) / 4}\right) \quad(x \geqq 1) \text {. }
$$

Looking at $m-\left[n^{c}\right]$ instead of $\left[n^{c}\right]$ we obtain similarly

THEOREM 2. For real $c$ with $1<c<3 / 2$, the number of representations of the natural number $m$ as $m=q+\left[n^{c}\right]$ with squarefree $q$ and natural $n$ equals

$$
6 \pi^{-2} m^{1 / c}+O_{c}\left(m^{(2 c+1) / 4 c}\right) .
$$

This can easily be generalized to $r$-free instead of squarefree. It should not be difficult to extend the method of [1] to cover the function class studied in [2].

\section{REFERENCES}

1. Jean-Marc Deshouillers, Sur la répartition des nombres $\left[n^{c}\right]$ dans les progressions arithmétiques, C.R. Acad. Sci. Paris, 277 (1973), Ser. A., 647-650.

2. Ivan F. Stux, Distribution of squarefree integers in non-linear sequences, Pacific J. Math., 59 (1975), 577-584.

Received June 26, 1977 and in revised form December 16, 1977.

TeChNische UnIVERSITÄT

D-3000 Hannover, Germany 


\section{PACIFIC JOURNAL OF MATHEMATICS}

\section{EDITORS}

RICHARD ARENS (Managing Editor)

University of California

Los Angeles, California 90024

C. W. CurTis

University of Oregon

Eugene, OR 97403

C. C. MOORE

University of California

Berkeley, CA 94720
J. DUGUNDJI

Department of Mathematics University of Southern California Los Angeles, California 90007

R. FinN AND J. Milgram Stanford University Stanford, California 94305

\section{ASSOCIATE EDITORS}

E. F. BECKENBACH

B. H. NeumanN

F. WOLF

K. YoSHIDA

\section{SUPPORTING INSTITUTIONS}

UNIVERSITY OF BRITISH COLUMBIA CALIFORNIA INSTITUTE OF TECHNOLOGY UNIVERSITY OF CALIFORNIA MONTANA STATE UNIVERSITY UNIVERSITY OF NEVADA, RENO NEW MEXICO STATE UNIVERSITY OREGON STATE UNIVERSITY UNIVERSITY OF OREGON
UNIVERSITY OF SOUTHERN CALIFORNIA

STANFORD UNIVERSITY

UNIVERSITY OF HAWAII

UNIVERSITY OF TOKYO

UNIVERSITY OF UTAH

WASHINGTON STATE UNIVERSITY

UNIVERSITY OF WASHINGTON 


\section{Pacific Journal of Mathematics \\ Vol. 78, No. $1 \quad$ March, 1978}

Simeon M. Berman, A class of isotropic distributions in $\mathbf{R}^{n}$ and their

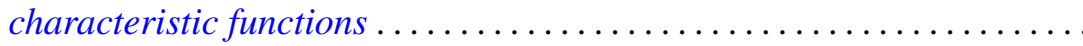

Ezra Brown and Charles John Parry, The 2-class group of biquadratic fields.

II ........................................ 11

Thomas E. Cecil and Patrick J. Ryan, Focal sets of submanifolds ....... 27

Joseph A. Cima and James Warren Roberts, Denting points in $B^{p} \ldots \ldots \ldots 41$

Thomas W. Cusick, Integer multiples of periodic continued fractions . . . . . 47

Robert D. Davis, The factors of the ramification sequence of a class of

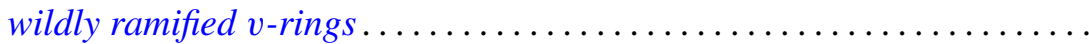

Robert Martin Ephraim, Multiplicative linear functionals of Stein

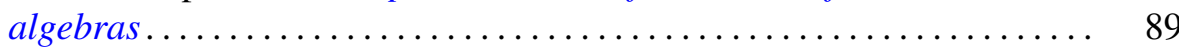

Philip Joel Feinsilver, Operator calculus . .................... 95

David Andrew Gay and William Yslas Vélez, On the degree of the splitting field of an irreducible binomial ..........................

Robert William Gilmer, Jr. and William James Heinzer, On the divisors of

monic polynomials over a commutative ring ..................

Robert E. Hartwig, Schur's theorem and the Drazin inverse .............

Hugh M. Hilden, Embeddings and branched covering spaces for three and four dimensional manifolds ............................

Carlos Moreno, The Petersson inner product and the residue of an Euler product. ...

Christopher Lloyd Morgan, On relations for representations of finite groups....

Ira J. Papick, Finite type extensions and coherence

$\mathrm{R}$. Michael Range, The Carathéodory metric and holomorphic maps on a class of weakly pseudoconvex domains ................

Donald Michael Redmond, Mean value theorems for a class of Dirichlet series

Daniel Reich, Partitioning integers using a finitely generated semigroup ...

Georg Johann Rieger, Remark on a paper of Stux concerning squarefree

numbers in non-linear sequences

Gerhard Rosenberger, Alternierende Produkte in freien Gruppen ..

Ryōtarō Satō, Contraction semigroups in Lebesgue space

Tord Sjödin, Capacities of compact sets in linear subspaces of $\mathbf{R}^{n}$

Robert Jeffrey Zimmer, Uniform subgroups and ergodic actions of exponential Lie groups......................... 